\title{
\begin{tabular}{l|l|l|l} 
Jurnal Kependidikan Dasar & $\begin{array}{l}\text { Volume : } \\
\text { Nomor }\end{array} 11$ \\
Tahun & $: 2019$ \\
\hline
\end{tabular}
}

\section{Identifikasi Problematika Mahasiswa Calon Guru SD/MI dalam Menyelesaikan Masalah Matematika Dasar}

\author{
Edi Irawan \\ Institut Agama Islam Negeri Ponorogo \\ nawariide1987@gmail.com
}

\begin{abstract}
Abstrak
Pentingnya keberadaan dan peran matematika dalam segala lini kehidupan menuntut untuk dipahami dan dikuasai dengan baik. Terlebih bagi guru atau calon guru sekolah dasar/madrasah ibtidaiyah yang akan menanamkan konsep matematika dasar pada para peserta didik. Penelitian ini dimaksudkan untuk mengidentifikasi permasalahan utama yang dihadapi oleh mahasiswa calon guru sekolah dasar/madrasah ibtidaiyah dalam menyelesaikan masalah matematika dasar. Penelitian ini merupakan penelitian deskriptif kualitatif dengan subjek penelitian mahasiswa Prodi PGMI IAIN Ponorogo. Hasil penelitian menunjukkan bahwa secara umum, terdapat dua problematika utama yang dihadapi mahasiswa calon guru sekolah dasar atau madrasah ibtidaiyah di IAIN Ponorogo. Pertama, masih rendahnya pemahaman terhadap konsep dasar matematika. Logika matematika merupakan materi dengan angka ketidakpahaman tertinggi dibandingkan materi lain. Ketidakpahaman konsep terjadi secara merata pada masingmasing kelompok mahasiswa, baik yang berasal dari MA, SMA, maupun SMK. Namun, angka ketidakpahaman konsep pada mahasiswa yang berasal dari SMK cenderung lebih tinggi. Kedua, terjadinya miskonsepsi. Miskonsepsi tertinggi terjadi pada materi bilangan dan operasi aljabar. Namun demikian, meskipun dalam jumlah terbatas, ditemukan juga miskonsepsi pada konsep matematika dasar lainnya. Miskonsepsi cenderung terjadi pada mahasiswa yang berasal dari SMA dan MA.
\end{abstract}

Kata Kunci: Matematika, Miskonsepsi, Penguasaan Konsep

\begin{abstract}
The The importance of existence and role of mathematics in all lines of life requires to be understood and mastered well. Especially for teachers or prospective elementary school/ madrasah ibtidaiyah (Islamic school) teachers who will instill the basic mathematical concepts for students. This research is intended to identify the main problems faced by prospective students of primary school/Islamic elementary school in solving basic math problems. This research is a qualitative descriptive study with research subjects as students of PGMI IAIN Ponorogo. Generally, the results of the study show that there are two main problems faced by prospective students of elementary school teachers or madrasah ibtidaiyah
\end{abstract}


(Islamic school) at IAIN Ponorogo. First, there is still a low understanding of the basic concepts of mathematics. Mathematical logic is the material with the highest number of incomprehension than other materials. The conceptual misunderstandings occur evenly in each group of students, both from MA (Islamic school), Senior High School and Vocational School. However, the number of misunderstanding of vocational students tends to be higher. Second, there is a misconception. The highest misconception occurs in material numbers and algebraic operations. Even though in limited numbers, misconceptions were found in other basic mathematical concepts. Misconceptions tend to occur in students from Senior High School and MA (Islamic school).

Keywords: Mathematics, Misconception, Mastery of Concepts

\section{A. PENDAHULUAN}

Matematika dikenal sebagai ratu sekaligus pelayan ilmu pengetahuan. Sebagai ratu ilmu karena matematika merupakan ilmu yang mandiri atau otonom, sehingga tanpa bantuan ilmu lain pun matematika dapat tumbuh dan berkembang untuk kebutuhan keilmuan matematika sendiri ${ }^{1}$. Sedangkan dikenal sebagai pelayan ilmu pengetahuan karena pengembangan ilmu pengetahuan lain sangat bergantung pada matematika ${ }^{2}$. Misalnya pada ilmu fisika, kimia, ekonomi yang memanfaatkan konsep fungsi, persamaan diferensial, dan juga integral.

Luasnya ruang lingkup matematika membuatnya tidak memiliki definisi tunggal. Pengertian matematika dinamis sesuai dengan kebutuhan dan perkembangan ilmu matematika itu sendiri. Namun

1 Erman Suherman, Strategi Pembelajaran Matematika Kontemporer (Bandung: UPI, 2003).

2 Susanah, Strategi Pembelajaran Matematika (Jakarta: Universitas Terbuka, 2008). demikian, matematika memiliki beberapa karakteristik, yaitu: 1) memiliki objek kajian abstrak; 2) bertumpu pada kesepakatan; 3) berpola pikir deduktif; 4) memiliki simbol yang kosong dari arti; 5) memperhatikan semesta pembicaraan (universal); dan 6) konsisten dalam sistemnya ${ }^{3}$.

Peran sebagai pelayan ilmu lain, membuat matematika menjadi mata pelajaran utama yang disampaikan sejak pendidikan dasar bahkan pendidikan anak usia dini hingga pendidikan tinggi ${ }^{4}$. Pendidikan matematika pada sekolah dasar memegang peranan penting dalam pembelajaran matematika pada jenjang berikutnya. Pendidikan di sekolah dasar menjadi fondasi dalam membangun pengetahuan matematika pada jenjang pendidikan berikutnya.

Kompetensi yang diharapkan melalui pembelajaran matematika di sekolah dasar beserta ruang lingkup materinya tercantum pada tabel 1 di bawah ini ${ }^{5}$.

Sebagai salah satu tolok ukur capaian proses pembelajaran matematika pada jenjang sekolah dasar adalah dengan melihat posisi Indonesia pada Trends in International Mathematics and Science Study (TIMSS). TIMSS merupakan sebuah penelitian tentang matematika dan pembelajaran matematika pada beberapa negara di dunia. Penelitian ini diinisiasi oleh the International Association for the Evaluation of Educational Achievement (IEA). Berikut adalah beberapa kondisi

\footnotetext{
3 Rachmadi Soedjadi, Kiat Pendidikan Matematika Di Indonesia: Konstatasi Keadaan Masa Kini Menuju Harapan Masa Depan (Direktorat Jenderal Pendidikan Tinggi, Departemen Pendidikan Nasional, 2000).

4 Soedjadi.

5 Menteri Pendidikan dan Kebudayaan, "Permendikbud Nomor 21 Tahun 2016 Tentang Standar Isi Pendidikan Dasar Dan Menengah," 2016.
} 


\section{Tabel 1. Kompetensi dan Ruang Lingkup Materi Matematika di Sekolah Dasar}

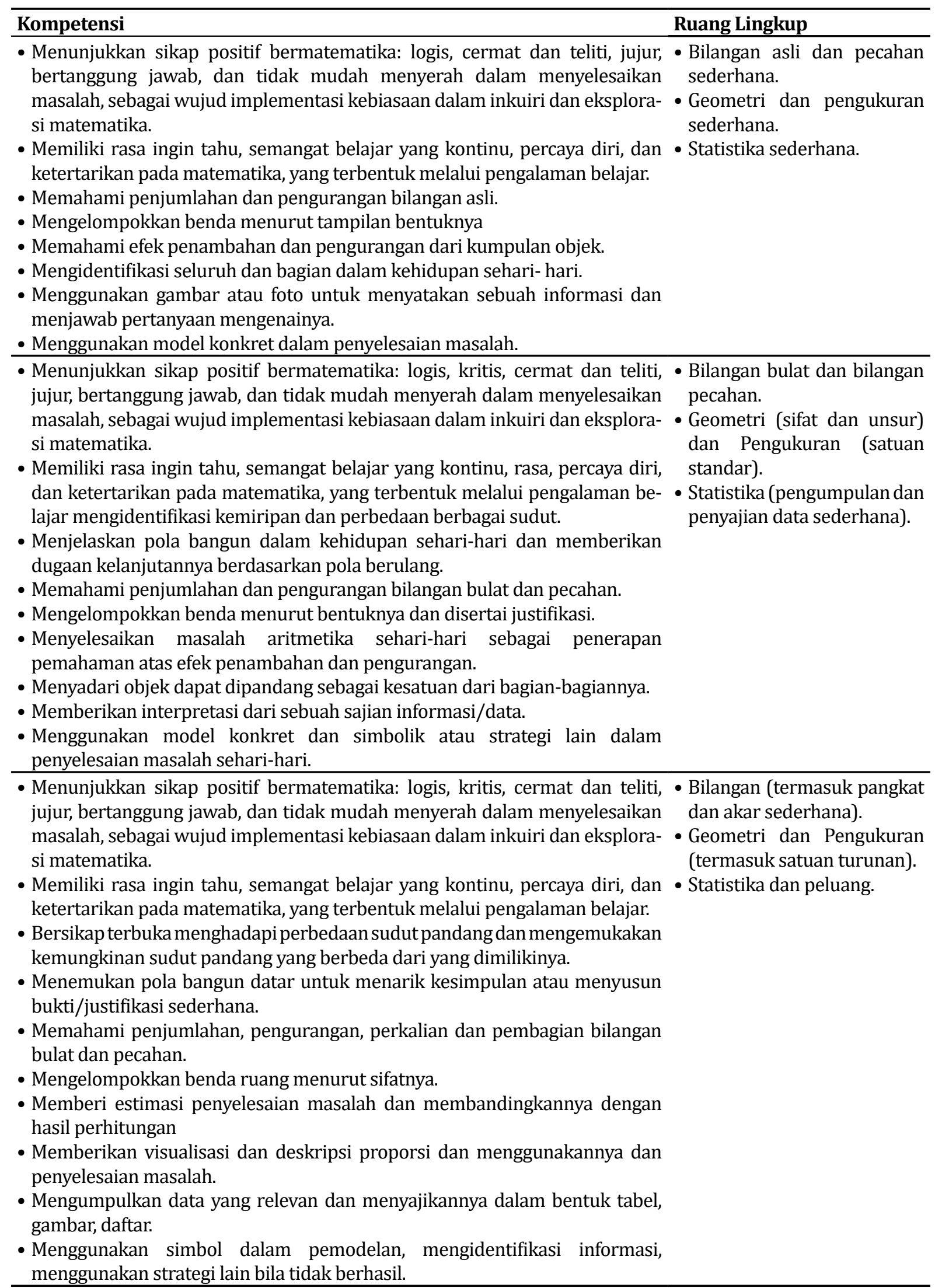


capaian Indonesia sebagaimana dipublikasikan pada TIMSS tahun $2015^{6}$.

Tabel 2. Perbandingan Rerata Persentase Jawaban Benar Soal Matematika

\begin{tabular}{|c|c|c|c|c|c|c|c|}
\hline \multirow[b]{2}{*}{ Negara } & \multirow[b]{2}{*}{ Rerata } & \multicolumn{3}{|c|}{ Domain } & \multicolumn{3}{|c|}{$\begin{array}{c}\text { Domain Kog- } \\
\text { nitif }\end{array}$} \\
\hline & & 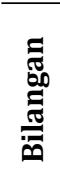 & 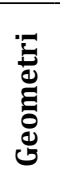 & 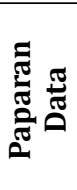 & 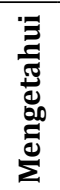 & 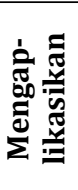 & $\frac{\bar{\pi}}{\tilde{\pi}}$ \\
\hline Indonesia & 26 & 24 & 28 & 31 & 32 & 24 & 20 \\
\hline Internasional & 50 & 49 & 50 & 57 & 56 & 48 & 44 \\
\hline
\end{tabular}

Secaraumum, rerata persentase capaian hasil belajar matematika di Indonesia di kancah internasional masih tertinggal. Indonesia berada di peringkat 45 dari total 50 negara yang menjadi sampel penelitian ${ }^{7}$. Bahkan, rerata kemampuan matematika siswa sekolah dasar di Indonesia berada jauh di bawah rerata skor matematika secara internasional. Mayoritas siswa kita belum mampu menggabungkan beberapa fakta, memadukan konsep, mengaplikasikan, apalagi mengomunikasikan hasil penalaran ${ }^{8}$. Hasil ini tentu tidak terlepas dari berbagai faktor penyebabnya, seperti kurikulum, sarana prasarana, guru, kemampuan awal peserta didik, dukungan orang tua dan lain-lain ${ }^{9}$.

Guru sekolah dasar atau madrasah ibtidaiyah perlu memiliki kemampuan dasar matematika yang baik. Terutama matematika dasar yang menjadi landasan dan bahan utama dalam mengajarkan matematika di sekolah dasar. Kemampuan ini akan menjadi salah satu faktor penting

\footnotetext{
6 Balitbang Kemendikbud, "TIMSS Infographic," 2016.

7 Kemendikbud.

8 Kemendikbud.

9 Ramlah Ramlah, Dani Firmansyah, and Hamzah Zubair, "Pengaruh Gaya Belajar Dan Keaktifan Siswa Terhadap Prestasi Belajar Matematika (Survey Pada SMP Negeri Di Kecamatan Klari Kabupaten Karawang)," Majalah Ilmiah SOLUSI 1, no. 03 (2015).
}

penunjang keberhasilan para peserta didik dalam memahami matematika ${ }^{10}$. Ketidakpahaman guru juga akan berimbas terhadap ketidakpahaman siswa. Terlebih juga apabila seorang guru atau calon guru mengalami miskonsepsi, tentu akan berpotensi menjadikan para peserta didik mengalami miskonsepsi juga.

Miskonsepsi dapat diartikan sebagai gagasan yang tidak sesuai dengan pengertian ilmiah atau pengertian yang dicetuskan oleh para pakar dalam suatu bidang serta bisa berupa pengertian yang tidak akurat terhadap konsep, penggunaan konsep yang salah, klasifikasi contohcontoh yang salah, kekacauan konsepkonsep yang berbeda dan hubungan hierarkis konsep-konsep yang tidak benar ${ }^{11}$. Miskonsepsi yang tidak teratasi dengan baik akan menular kepada orang lain. Terlebih bagi seorang guru, tentu akan berimbas pada peserta didiknya.

Pemahaman konsep diidentifikasi menggunakan certainty of response indeks (tingkat keyakinan jawaban) ${ }^{12}$. Setiap jawaban pada masing-masing butir, dilengkapi dengan tingkat keyakinan akan jawaban tersebut. Tingkat keyakinan terdiri dari tiga tingkatan, yaitu yakin/ sangat yakin, ragu-ragu, dan menebak sebagian atau seluruhnya. Selanjutnya, kombinasi antara jawaban dan tingkat keyakinan jawaban tersebut digunakan

10 Rezky Agung Herutomo and Tri Edi Mulyono Saputro, "Analisis Kesalahan Dan Miskonsepsi Siswa Kelas VIII Pada Materi Aljabar," Edusentris 1, no. 2 (2014): 134-145.

11 Edi Irawan, Riyadi Riyadi, and Triyanto Triyanto, "Analisis Miskonsepsi Mahasiswa STKIP PGRI Pacitan Pada Mata Kuliah Pengantar Dasar Matematika Pokok Bahasan Logika Ditinjau Dari Gaya Kognitif Mahasiswa," 2012.

12 Edi Irawan, "Analisis Miskonsepsi Mahasiswa STKIP PGRI Pacitan Pada Mata Kuliah Matematika Dasar Pokok Bahasan Logika Ditinjau Dari Gaya Kognitif Mahasiswa" (PhD Thesis, Thesis pada PPsUNS: Tidak dipublikasikan, 2012). 
untuk mengidentifikasi apakah mahasiswa tersebut memahami konsep dengan baik, memahami konsep sebagian, mengalami miskonsepsi, dan tidak tahu konsep, sebagaimana tercantum pada tabel di bawah ini ${ }^{13}$.

Tabel 3. Interpretasi Jawaban dan Keyakinan Jawaban Mahasiswa

\begin{tabular}{lll}
\hline \multicolumn{1}{c}{ Tingkat } & \multicolumn{1}{c}{ Jawaban Mahasiswa } \\
\cline { 2 - 3 } Keyakinan & \multicolumn{1}{c}{ Benar } & \multicolumn{1}{c}{ Salah } \\
\hline Yakin & Memahami konsep & Miskonsepsi \\
Ragu-ragu & $\begin{array}{l}\text { Memahami konsep } \\
\text { sebagian }\end{array}$ & Tidak tahu konsep \\
Menebak & Tidak tahu konsep & Tidak tahu konsep \\
\hline
\end{tabular}

Faktor penentu lain adalah input peserta didik yang heterogen. Demikian halnya dengan heterogenitas yang terjadi pada Program Studi Pendidikan Guru Madrasah Ibtidaiyah (PGMI) di Institut Agama Islam Negeri Ponorogo. Para mahasiswa PGMI memiliki latar belakang pendidikan yang bervariasi. Setidaknya terdapat tiga kelompok besar, yaitu para mahasiswa alumni Madrasah Aliyah (MA), alumni Sekolah Menengah Atas (SMA), dan Sekolah Menengah Kejuruan (SMK). Bahkan, apabila diteliti lebih dalam, alumni MA ada yang berasal dari jurusan agama, jurusan ilmu pengetahuan alam (IPA), ilmu pengetahuan sosial (IPS). Demikian halnya untuk para mahasiswa alumni SMA, ada yang berasal dari jurusan ilmu pengetahuan alam (IPA) dan ilmu pengetahuan sosial (IPS). Terlebih untuk alumni SKM berasal dari berbagai jurusan yang sangat bervariasi. Hal ini tentu berimplikasi pada

\footnotetext{
13 Irawan, Riyadi, and Triyanto, "Analisis Miskonsepsi Mahasiswa STKIP PGRI Pacitan Pada Mata Kuliah Pengantar Dasar Matematika Pokok Bahasan Logika Ditinjau Dari Gaya Kognitif Mahasiswa"; Lutfia Afifatul Ainiyah and Sugiyono Sugiyono, "Identifikasi Miskonsepsi Siswa Dalam Materi Geometri Pada Pembelajaran Matematika Siswa Kelas VIII SMP Negeri 1 Punggelan," Jurnal Pendidikan Matematika-S1 5, no. 1 (2016).
}

kemampuan awal mahasiswa yang sangat heterogen.

Latar belakang pendidikan ini tentu akan berdampak pada kemampuan dasar matematika mahasiswa. Mengingat kedalaman dan keluasan materi yang dipelajari pada masing-masing jurusan dan bentuk sekolah menengah sangat berbeda. Ruang lingkup materi antara jurusan IPA tentu akan berbeda dengan IPS dan agama. Terlebih dengan para lulusan SMK tentu akan berbeda dengan lulusan SMA dan MA.

Berpijak dari kondisi tersebut, penelitian ini berupaya untuk mengupas problematika yang dihadapi oleh para mahasiswa calon guru sekolah dasar atau madrasah ibtidaiyah dalam menyelesaikan soal-soal matematika dasar. Tujuannya adalah untuk memberikan gambaran nyata tentang kondisi input mahasiswa yang sesungguhnya. Hal ini menjadi sangat penting bagi para Bapak/Ibu Dosen untuk mengembangkan sebuah pendekatan, strategi, atau metode yang mampu menyelesaikan dan mengoptimalkan disparitas penguasaan konsep awal yang ada.

\section{B. METODE PENELITIAN}

Penelitian ini termasuk penelitian deskriptif kualitatif dengan metode studi kasus. Penelitian kualitatif adalah penelitian yang bermaksud untuk memahami fenomena tentang apa yang dialami oleh subjek penelitian secara holistik, dan dengan cara deskripsi dalam bentuk kata-kata dan bahasa, pada suatu konteks khusus yang alamiah dan dengan memanfaatkan berbagai metode alamiah $^{14}$. Penelitian deskriptif merupakan suatu penelitian yang ditujukan untuk

\footnotetext{
${ }^{14}$ Lexy J. Moleong, Metode Penelitian Kualitatif (Bandung: Remaja Rosdakarya, 2007).
} 
mendeskripsikan suatu keadaan atau fenomena-fenomena apa adanya ${ }^{15}$. Sedangkan metode penelitian studi kasus adalah suatu penelitian yang dilakukan terhadap suatu "kesatuan sistem"16. Pada penelitian ini, kasus yang akan diteliti dan dideskripsikan merupakan situasi khusus, yaitu problematika yang dihadapi oleh para mahasiswa calon guru sekolah dasar atau madrasah ibtidaiyah dalam menyelesaikan soal-soal matematika dasar.

Pada penelitian ini, peneliti sebagai instrumen utama dibantu dengan instrumen lain sebagai penunjang. Sesuai dengan bentuk pendekatan penelitian kualitatif dan sumber data yang akan digunakan, maka teknik pengumpulan data yang digunakan menggunakan metode dokumentasi, metode tes, dan wawancara. Ketiganya, digunakan untuk menggali data lebih mendalam tentang problematika yang dihadapi oleh para mahasiswa.

Data yang terkumpul selanjutnya diolah menggunakan teknik analisis data model Miles \& Huberman. Teknik analisis data model Miles \& Huberman meliputi tahap reduksi data (data reduction), penyajian data (data display), serta penarikan kesimpulan dan verifikasi (conclusion drawing/verification $)^{17}$. Keabsahan data dijaga dengan menggunakan wawancara mendalam dan triangulasi waktu.

Penelitian ini dilaksanakan pada Program Studi Pendidikan Guru Madrasah Ibtidaiyah (PGMI) Institut Agama Islam Negeri Ponorogo. Adapun yang menjadi subjek penelitian adalah mahasiswa baru tahun akademik 2018/2019, kelas E, F, dan
G. Pengambilan data dilakukan pada bulan September sampai Oktober tahun 2018.

Secara teknis, pelaksanaan penelitian terdiri dari 4 (empat) tahapan, yaitu: pertama, tahap pra-lapangan, yang meliputi: menyusun rancangan penelitian dan menyiapkan instrumen bantu berupa angket dan tes. Kedua, tahap pekerjaan lapangan, yaitu pengumpulan data melalui penyebaran angket dan tes serta wawancara. Ketiga, tahap analisis data, yang dilaksanakan pada saat dan sesudah pengumpulan data. Keempat, tahap penyusunan artikel laporan hasil penelitian.

\section{HASIL DAN PEMBAHASAN Profil Subjek Penelitian}

Berikut adalah profil mahasiswa baru PGMI menurut jenis kelamin dan latar belakang pendidikannya.

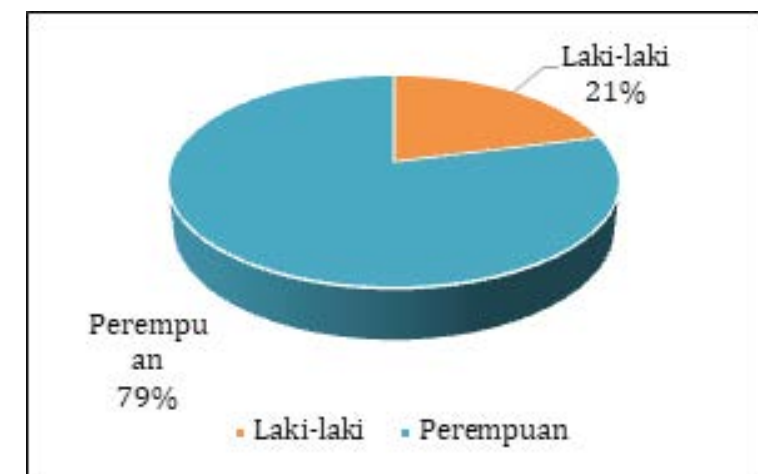

Gambar 1. Profil Responden Menurut Jenis Kelamin

Gambar 1 di atas menunjukkan bahwa sebagian besar peminat calon guru PGMI adalah perempuan. Hal ini menunjukkan bahwa minat siswa laki-laki untuk menjadi seorang guru di sekolah dasar atau madrasah ibtidaiyah rendah.

\footnotetext{
15 Nana Syaodih Sukmadinata, Metode Penelitian Pendidikan (Bandung: Remaja Rosdakarya, 2005).

16 Sukmadinata.

17 Matthew B. Miles and A. Michael Huberman, Qualitative Data Analysis: An Expanded Sourcebook (London: Sage Publications, 1994).
} 


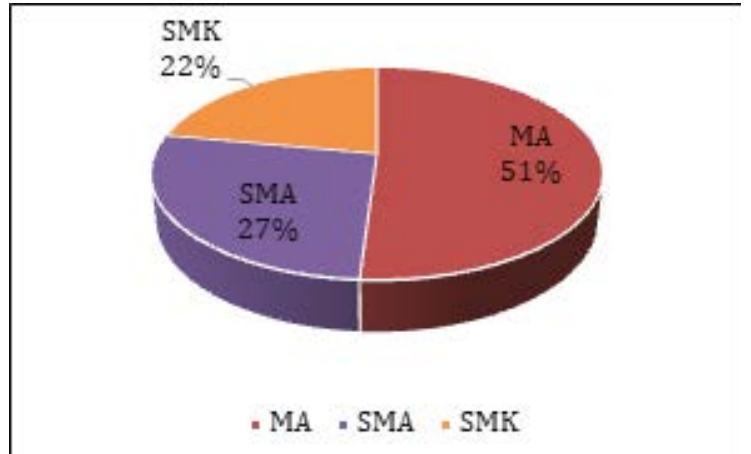

Gambar 2. Profil Responden Menurut Asal Sekolah

Gambar 2 di atas menunjukkan bahwa sebagian besar mahasiswa calon guru SD/ MI di IAIN Ponorogo merupakan lulusan MA (51\%), disusul SMA (27\%), dan SMK (22\%). Hal ini menunjukkan heterogenitas input peserta didik baru pada jurusan PGMI IAIN Ponorogo. Sementara apabila ditinjau dari status sekolah, negeri atau swasta, dapat dilihat pada gambar 3 di bawah ini.

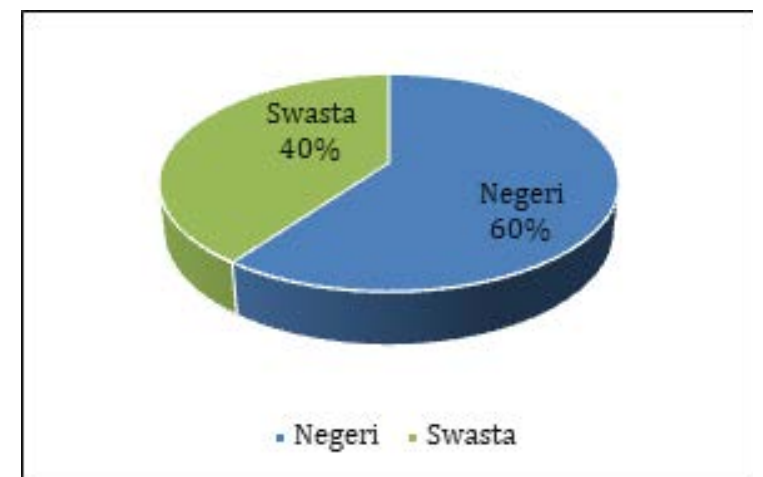

Gambar 3. Profil Responden Menurut Status Sekolah

Selanjutnya, secara lebih spesifik, apabila dilihat dari jurusan pada sekolah asal, dapat digambarkan sebagai berikut.

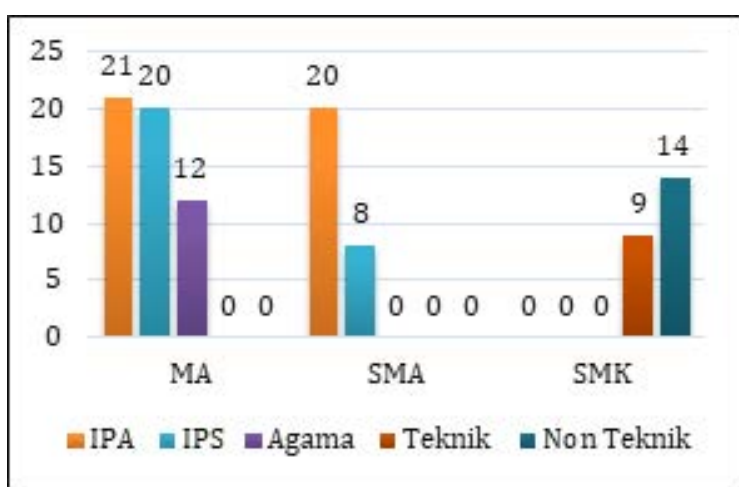

Gambar 4. Sebaran Responden Menurut Jurusan/Program Keahlian Sebelumnya

Berdasarkan gambar tersebut, terlihat bahwa sebagian besar calon guru SD/MI yang berasal dari SMA dan MA berlatar belakang jurusan IPA. Namun untuk siswa yang berasal dari SMK, sebagian besar berlatar belakang jurusan non teknik.

\section{Hasil Tes Matematika Dasar}

Berdasarkan tes matematika dasar yang dilakukan terhadap subjek penelitian, diperoleh rerata dan standar deviasi nilai mahasiswa sebagaimana tabel 4 di bawah ini.

Tabel 4. Rerata dan Standar Deviasi Nilai Matematika Dasar Mahasiswa

\begin{tabular}{llcc}
\hline $\begin{array}{c}\text { Latar Belakang Pendidi- } \\
\text { kan }\end{array}$ & Rerata & $\begin{array}{c}\text { Standar } \\
\text { Deviasi }\end{array}$ \\
\hline MA & IPA & 71,57 & 14,56 \\
& IPS & 58,90 & 13,88 \\
& Agama & 67,67 & 14,63 \\
& Marginal & 65,91 & 15,16 \\
\hline SMA & IPA & 70,65 & 13,80 \\
& IPS & 62,75 & 20,69 \\
& Marginal & 68,39 & 16,07 \\
\hline SMK & Teknik & 68,10 & 8,91 \\
& Non Teknik & 66,71 & 11,02 \\
& Marginal & 67,29 & 10,01 \\
\hline
\end{tabular}

Tabel 4 di atas menunjukkan bahwa pada mahasiswa prestasi belajar matematika dasar secara umum pada lulusan MA, SMA, dan SMK tidak terdapat perbedaan yang signifikan. Namun prestasi mahasiswa yang berasal dari jurusan IPA cenderung lebih tinggi dari pada mahasiswa jurusan 
lainnya. Hal ini tentu tidak terlepas dari proses pembelajaran sebelumnya. Mahasiswa jurusan IPA mendapatkan porsi belajar matematika lebih lama dan materi yang lebih luas dari pada jurusan lainnya.

Pemahaman mahasiswa terhadap masing-masing materi, dapat diklasifikasikan dalam tiga kategori, yaitu paham konsep, tidak paham konsep, dan mengalami miskonsepsi. Pemahaman tersebut diklasifikasikan juga berdasarkan latar belakang pendidikannya.

\section{Pemahaman Terhadap Konsep Bilangan dan Operasi Aljabar}

Berikut adalah proporsi pemahaman mahasiswa pada konsep bilangan dan operasi aljabar yang meliputi materi pengertian bilangan (bulat, asli, cacah, pecahan), penjumlahan, pengurangan, perkalian, pembagian, pangkat, akar, logaritma, persamaan kuadrat, sistem persamaan linier, dan pertidaksamaan.

Tabel 5. Proporsi Pemahaman Terhadap Konsep Bilangan dan Operasi Aljabar

\begin{tabular}{llccc}
\hline $\begin{array}{c}\text { Latar Belakang } \\
\text { Pendidikan }\end{array}$ & $\begin{array}{c}\text { Paham } \\
\text { Konsep }\end{array}$ & $\begin{array}{c}\text { Tidak } \\
\text { Paham }\end{array}$ & $\begin{array}{c}\text { Miskon- } \\
\text { sepsi }\end{array}$ \\
\hline MA & IPA & $67 \%$ & $24 \%$ & $10 \%$ \\
& IPS & $60 \%$ & $35 \%$ & $5 \%$ \\
& Agama & $67 \%$ & $25 \%$ & $8 \%$ \\
& Marginal & $64 \%$ & $28 \%$ & $8 \%$ \\
\hline SMA & IPA & $75 \%$ & $15 \%$ & $10 \%$ \\
& IPS & $50 \%$ & $38 \%$ & $13 \%$ \\
& Marginal & $68 \%$ & $21 \%$ & $11 \%$ \\
\hline SMK & Teknik & $60 \%$ & $40 \%$ & $0 \%$ \\
& Non Teknik & $57 \%$ & $36 \%$ & $7 \%$ \\
& Marginal & $58 \%$ & $38 \%$ & $4 \%$ \\
\hline & Rerata & $63 \%$ & $29 \%$ & $7 \%$ \\
\hline
\end{tabular}

Berdasarkan tabel 5 di atas menunjukkan bahwa mahasiswa yang memahami konsep bilangan dan operasi aljabar berkisar pada angka 63\% responden yang memahami konsep dengan benar.
Sisanya tidak memahami konsep dengan baik dan sebagian juga terjadi miskonsepsi pada materi bilangan dan operasi aljabar. Pemahaman konsep bilangan dan operasi aljabar tertinggi terjadi pada mahasiswa yang berasal dari SMA (68\%), kemudian disusul dari MA (64\%), dan dari SMK (58\%). Sedangkan persentase ketidakpahaman mahasiswa terhadap konsep bilangan dan operasi aljabar berkisar pada angka 29\%. Artinya sebanyak 29\% mahasiswa belum memahami konsep bilangan dan operasi aljabar dengan baik dan benar. Sementara miskonsepsi terjadi secara merata pada masing-masing kelompok, baik mahasiswa yang berlatar belakang pendidikan MA, SMA, maupun SMK.

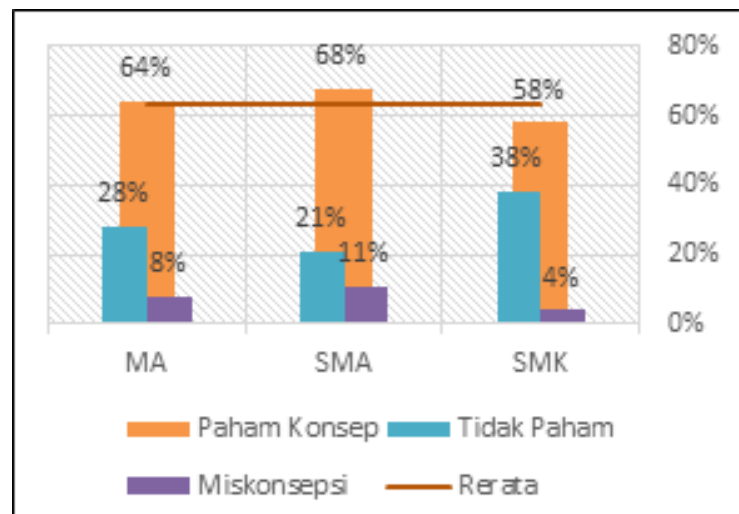

Gambar 5. Pemahaman Mahasiswa Terhadap Konsep Bilangan dan Operasi Aljabar Menurut Latar Belakang Pendidikan Sebelumnya

Ketidakpahaman konsep terjadi secara merata pada materi pengertian bilangan (bulat, asli, cacah, pecahan), penjumlahan, pengurangan, perkalian, pembagian, pangkat, akar, logaritma, persamaan kuadrat, sistem persamaan linier, dan pertidaksamaan. Sementara miskonsepsi terjadi pada beberapa konsep bilangan dan operasi aljabar. Pertama, miskonsepsi terjadi pada konsep bilangan asli dan bilangan cacah. Pemahaman mahasiswa terhadap keduanya kerap kali tertukar. Sebagian mahasiswa 
menganggap bilangan asli sebagai bilangan cacah dan sebaliknya bilangan cacah dianggap bilangan asli. Kedua, miskonsepsi pada konsep penjumlahan bilangan pecahan. Sebagian mahasiswa melakukan penjumlahan bilangan pecahan dengan menjumlah pembilang sekaligus penyebutnya. Ketiga, miskonsepsi pada konsep penyelesaian pertidaksamaan yang melibatkan bilangan pecahan. Miskonsepsi penyelesaian operasi bilangan pecahan terjadi pada saat penyamaan penyebut yang tidak diikuti dengan penyesuaian terhadap pembilang.

\section{Pemahaman Terhadap Konsep}

\section{Himpunan dan Relasi antar Himpunan}

Berikut adalah proporsi pemahaman mahasiswa pada konsep himpunan dan relasi antar himpunan yang meliputi materi pengertian himpunan, himpunan kuasa, gabungan, irisan, komplemen, penjumlahan, pengurangan, dan aplikasi konsep relasi antar himpunan dalam menyelesaikan permasalahan sehari-hari.

Tabel 6. Proporsi Pemahaman Terhadap Konsep Himpunan dan Relasi antar Himpunan

\begin{tabular}{llccc}
\hline $\begin{array}{c}\text { Latar Belakang } \\
\text { Pendidikan }\end{array}$ & $\begin{array}{c}\text { Paham } \\
\text { Konsep }\end{array}$ & $\begin{array}{c}\text { Tidak } \\
\text { Paham }\end{array}$ & $\begin{array}{c}\text { Miskon- } \\
\text { sepsi }\end{array}$ \\
\hline MA & IPA & $62 \%$ & $33 \%$ & $5 \%$ \\
& IPS & $60 \%$ & $40 \%$ & $0 \%$ \\
& Agama & $67 \%$ & $33 \%$ & $0 \%$ \\
& Marginal & $62 \%$ & $36 \%$ & $2 \%$ \\
\hline SMA & IPA & $70 \%$ & $25 \%$ & $5 \%$ \\
& IPS & $50 \%$ & $38 \%$ & $13 \%$ \\
& Marginal & $64 \%$ & $29 \%$ & $7 \%$ \\
\hline \multirow{2}{*}{ SMK } & Teknik & $60 \%$ & $40 \%$ & $0 \%$ \\
& Non Teknik & $50 \%$ & $50 \%$ & $0 \%$ \\
& Marginal & $54 \%$ & $46 \%$ & $0 \%$ \\
\hline & Rerata & $60 \%$ & $37 \%$ & $3 \%$ \\
\hline
\end{tabular}

Berdasarkan tabel 6 di atas menunjukkan bahwa mahasiswa yang memahami konsep himpunan dan relasi antar him- punan berkisar pada angka $60 \%$ responden yang memahami konsep dengan benar. Sisanya tidak memahami konsep dengan baik dan sebagian juga terjadi miskonsepsi pada materi himpunan dan relasi antar himpunan. Pemahaman konsep himpunan dan relasi antar himpunan tertinggi terjadi pada mahasiswa yang berasal dari SMA (64\%), kemudian disusul dari MA (62\%), dan dari SMK (54\%). Sedangkan persentase ketidakpahaman mahasiswa terhadap konsep himpunan dan relasi antar himpunan berkisar pada angka 37\%. Artinya sebanyak 37\% mahasiswa belum memahami konsep himpunan dan relasi antar himpunan dengan baik dan benar. Sementara itu, miskonsepsi terjadi pada mahasiswa yang berlatar belakang pendidikan MA dan SMA. Mahasiswa yang berlatar belakang pendidikan SMK tidak mengalami miskonsepsi pada materi himpunan dan relasi antar himpunan, namun lebih cenderung tidak tahu konsep.

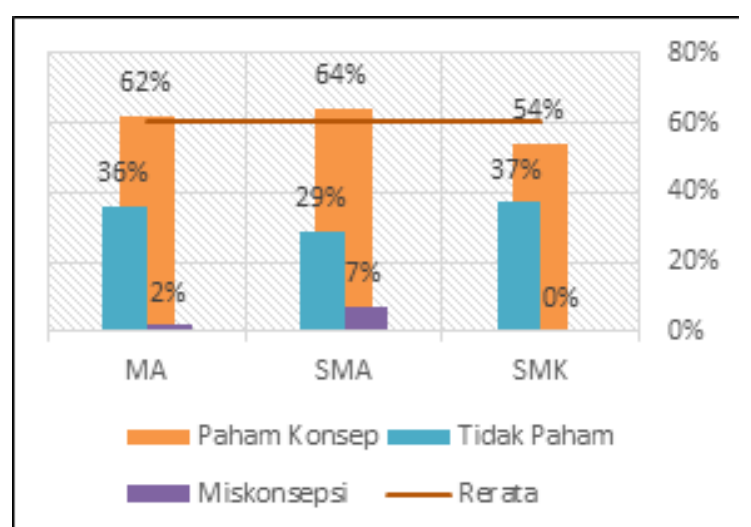

Gambar 6. Pemahaman Mahasiswa Terhadap Konsep Himpunan dan Relasi antar Himpunan Menurut Latar Belakang Pendidikan Sebelumnya

Ketidakpahaman mahasiswa terhadap konsep himpunan dan relasi antar himpunan terjadi secara merata pada materi pengertian himpunan, himpunan kuasa, gabungan, irisan, komplemen, penjumlahan, pengurangan, dan aplikasi 
konsep relasi antar himpunan dalam menyelesaikan permasalahan sehari-hari. Sementara miskonsepsi terjadi padakonsep penjumlahan dan pengurangan himpunan. Penjumlahan himpunan diasumsikan sama dengan himpunan gabungan sedangkan pengurangan himpunan diasumsikan sama dengan irisan.

\section{Pemahaman Terhadap Konsep Geometri dan Pengukuran}

Berikut adalah proporsi pemahaman mahasiswa pada konsep geometri dan pengukuran yang meliputi materi bangun datar, bangun ruang, luas, keliling, volume, kesebangunan, trigonometri, sistem koordinat, jarak, kelajuan, dan kecepatan.

Tabel 7. Proporsi Pemahaman Terhadap

Konsep Geometri dan Pengukuran

\begin{tabular}{|c|c|c|c|c|}
\hline \multicolumn{2}{|c|}{$\begin{array}{c}\text { Latar Belakang } \\
\text { Pendidikan }\end{array}$} & \multirow{2}{*}{$\begin{array}{c}\begin{array}{c}\text { Paham } \\
\text { Konsep }\end{array} \\
57 \%\end{array}$} & \multirow{2}{*}{$\begin{array}{c}\begin{array}{c}\text { Tidak } \\
\text { Paham }\end{array} \\
38 \% \\
\end{array}$} & \multirow{2}{*}{$\begin{array}{c}\begin{array}{c}\text { Miskon- } \\
\text { sepsi }\end{array} \\
5 \% \\
\end{array}$} \\
\hline MA & IPA & & & \\
\hline & IPS & $55 \%$ & $45 \%$ & $0 \%$ \\
\hline & Agama & $58 \%$ & $33 \%$ & $8 \%$ \\
\hline & Marginal & $57 \%$ & $40 \%$ & $4 \%$ \\
\hline \multirow[t]{3}{*}{ SMA } & IPA & $65 \%$ & $30 \%$ & $5 \%$ \\
\hline & IPS & $63 \%$ & $38 \%$ & $0 \%$ \\
\hline & Marginal & $64 \%$ & $32 \%$ & $4 \%$ \\
\hline \multirow[t]{3}{*}{ SMK } & Teknik & $50 \%$ & $50 \%$ & $0 \%$ \\
\hline & Non Teknik & $43 \%$ & $57 \%$ & $0 \%$ \\
\hline & Marginal & $46 \%$ & $54 \%$ & $0 \%$ \\
\hline \multicolumn{2}{|r|}{ Rerata } & $56 \%$ & $42 \%$ & $2 \%$ \\
\hline
\end{tabular}

Berdasarkan tabel 7 di atas menunjukkan bahwa mahasiswa yang memahami konsep geometri dan pengukuran berkisar pada angka 56\% responden yang memahami konsep dengan benar. Sisanya tidak memahami konsep dengan baik dan sebagian juga terjadi miskonsepsi pada materi geometri dan pengukuran. Pemahaman konsep geometri dan pengukuran tertinggi terjadi pada mahasiswa yang berasal dari SMA (64\%), kemudian disusul dari MA (57\%), dan dari SMK (46\%). Sedangkan persentase ketidakpahaman mahasiswa terhadap konsep geometri dan pengukuran berkisar pada angka 42\%. Artinya sebanyak 42\% mahasiswa belum memahami konsep geometri dan pengukuran dengan baik dan benar. Sementara itu, miskonsepsi terjadi pada mahasiswa yang berlatar belakang pendidikan MA dan SMA. Mahasiswa yang berlatar belakang pendidikan SMK tidak mengalami miskonsepsi pada materi geometri dan pengukuran, namun lebih cenderung tidak tahu konsep.

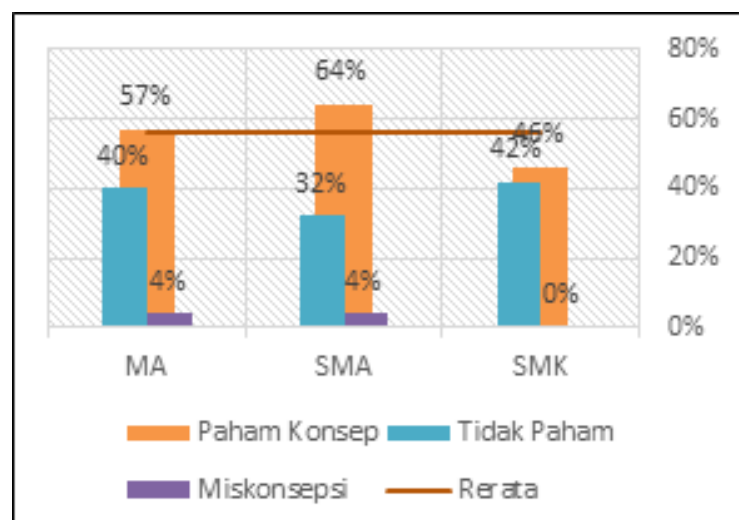

Gambar 7. Pemahaman Mahasiswa

Terhadap Konsep Geometri dan Pengukuran Menurut Latar Belakang Pendidikan Sebelumnya

Ketidakpahaman konsep terjadi secara merata pada materi bangun datar, bangun ruang, luas, keliling, volume, kesebangunan, trigonometri, sistem koordinat, jarak, kelajuan, dan kecepatan. Sementara miskonsepsi terjadi pada materi kelajuan dan kecepatan. Sebagian mahasiswa memahami kelajuan sebagai kecepatan dan kecepatan sebagai kelajuan.

\section{Pemahaman Terhadap Konsep Statistika dan Peluang}

Berikut adalah proporsi pemahaman mahasiswa pada konsep statistika dan peluang yang meliputi materi penyajian 
data, mean, median, modus, variansi, standar deviasi, kuartil, peluang, permutasi, dan kombinasi.

Tabel 8. Proporsi Pemahaman Terhadap Konsep Statistika dan Peluang

\begin{tabular}{|l|l|c|c|c|}
\hline \multicolumn{2}{|c|}{$\begin{array}{c}\text { Latar Belakang } \\
\text { Pendidikan }\end{array}$} & $\begin{array}{c}\text { Paham } \\
\text { Konsep }\end{array}$ & $\begin{array}{c}\text { Tidak } \\
\text { Paham }\end{array}$ & $\begin{array}{c}\text { Miskon- } \\
\text { sepsi }\end{array}$ \\
\hline \multirow{3}{*}{ MA } & IPA & $52 \%$ & $38 \%$ & $10 \%$ \\
\cline { 2 - 5 } & IPS & $50 \%$ & $45 \%$ & $5 \%$ \\
\cline { 2 - 5 } & Agama & $50 \%$ & $42 \%$ & $8 \%$ \\
\cline { 2 - 5 } & Marginal & $51 \%$ & $42 \%$ & $8 \%$ \\
\hline \multirow{3}{*}{ SMA } & IPA & $65 \%$ & $30 \%$ & $5 \%$ \\
\cline { 2 - 5 } & IPS & $50 \%$ & $38 \%$ & $13 \%$ \\
\cline { 2 - 5 } & Marginal & $61 \%$ & $32 \%$ & $7 \%$ \\
\hline \multirow{3}{*}{ SMK } & Teknik & $60 \%$ & $40 \%$ & $0 \%$ \\
\cline { 2 - 5 } & Non Teknik & $36 \%$ & $57 \%$ & $7 \%$ \\
\cline { 2 - 5 } & Marginal & $46 \%$ & $50 \%$ & $4 \%$ \\
\hline \multicolumn{2}{|c|}{ Rerata } & $52 \%$ & $41 \%$ & $6 \%$ \\
\hline
\end{tabular}

Berdasarkan tabel 8 di atas menunjukkan bahwa mahasiswa yang memahami konsep statistika dan peluang berkisar pada angka 52\% responden yang memahami konsep dengan benar. Sisanya tidak memahami konsep dengan baik dan sebagian juga terjadi miskonsepsi pada materi statistika dan peluang. Pemahaman konsep statistika dan peluang tertinggi terjadi pada mahasiswa yang berasal dari SMA (61\%), kemudian disusul dari MA (51\%), dan dari SMK (46\%). Sedangkan persentase ketidakpahaman mahasiswa terhadap konsep statistika dan peluang berkisar pada angka 41\%. Artinya sebanyak 41\% mahasiswa belum memahami konsep statistika dan peluang dengan baik dan benar. Berdasarkan tabel 8 di atas juga diketahui bahwa miskonsepsi terjadi secara merata pada masing-masing kelompok, baik mahasiswa yang berlatar belakang pendidikan MA, SMA, maupun SMK.

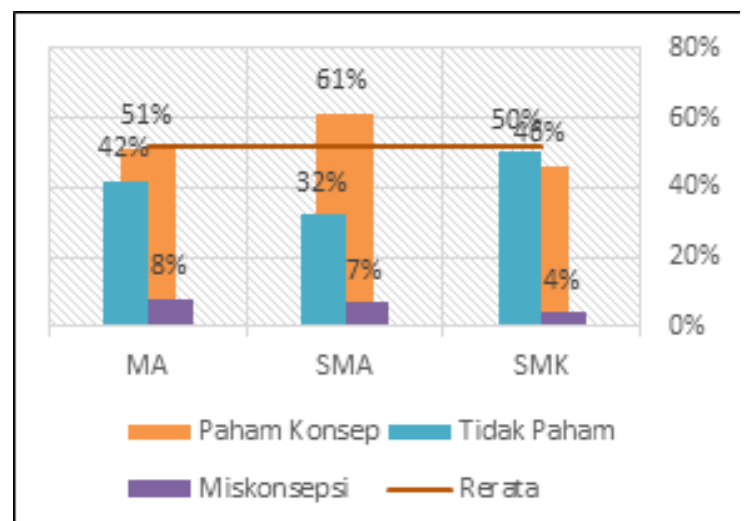

Gambar 8. Pemahaman Mahasiswa Terhadap Konsep Statistika dan Peluang Menurut Latar Belakang Pendidikan Sebelumnya

Ketidakpahaman mahasiswa terhadap konsep statistika dan peluang terjadi secara merata pada materi penyajian data, mean, median, modus, variansi, standar deviasi, kuartil, peluang, permutasi, dan kombinasi. Sementara itu, miskonsepsi terjadi pada materi permutasi dan kombinasi. Sebagian mahasiswa mengalami kekacauan konsep antara permutasi dan kombinasi.

\section{Pemahaman Terhadap Konsep Logika Matematika}

Berikut adalah proporsi pemahaman mahasiswa pada konsep logika matematika yang meliputi materi pernyataan dan bukan pernyataan, modus ponens, modus tollens, silogisme, penarikan simpulan secara langsung, penarikan simpulan secara tidak langsung dengan kontradiksi, penarikan simpulan secara tidak langsung dengan kontraposisi, penarikan simpulan dengan induksi matematika.

Tabel 9. Proporsi Pemahaman Terhadap Konsep Logika Matematika

\begin{tabular}{clccc}
\hline $\begin{array}{c}\text { Latar Belakang } \\
\text { Pendidikan }\end{array}$ & $\begin{array}{c}\text { Paham } \\
\text { Konsep }\end{array}$ & $\begin{array}{c}\text { Tidak } \\
\text { Paham }\end{array}$ & $\begin{array}{c}\text { Miskon- } \\
\text { sepsi }\end{array}$ \\
\hline MA & IPA & $43 \%$ & $52 \%$ & $5 \%$ \\
& IPS & $40 \%$ & $60 \%$ & $0 \%$ \\
& Agama & $42 \%$ & $58 \%$ & $0 \%$ \\
& Marginal & $42 \%$ & $57 \%$ & $2 \%$ \\
\hline
\end{tabular}




\begin{tabular}{clccc}
\hline $\begin{array}{c}\text { Latar Belakang } \\
\text { Pendidikan }\end{array}$ & $\begin{array}{c}\text { Paham } \\
\text { Konsep }\end{array}$ & $\begin{array}{c}\text { Tidak } \\
\text { Paham }\end{array}$ & $\begin{array}{c}\text { Miskon- } \\
\text { sepsi }\end{array}$ \\
\hline SMA & IPA & $45 \%$ & $50 \%$ & $5 \%$ \\
& IPS & $38 \%$ & $63 \%$ & $0 \%$ \\
& Marginal & $43 \%$ & $54 \%$ & $4 \%$ \\
\hline \multirow{2}{*}{ SMK } & Teknik & $30 \%$ & $70 \%$ & $0 \%$ \\
& Non Teknik & $29 \%$ & $71 \%$ & $0 \%$ \\
& Marginal & $29 \%$ & $71 \%$ & $0 \%$ \\
\hline \multicolumn{2}{c}{ Rerata } & $38 \%$ & $60 \%$ & $2 \%$ \\
\hline
\end{tabular}

Berdasarkan tabel 9 di atas menunjukkan bahwa mahasiswa yang memahami konsep logika matematika berkisar pada angka 38\% responden yang memahami konsep dengan benar. Sisanya tidak memahami konsep dengan baik dan sebagian juga terjadi miskonsepsi pada materi logika matematika. Pemahaman konsep logika matematika tertinggi terjadi pada mahasiswa yang berasal dari SMA (43\%), kemudian disusul dari MA (42\%), dan dari SMK (29\%). Sedangkan persentase ketidakpahaman mahasiswa terhadap konsep logika matematika berkisar pada angka 60\%. Artinya sebanyak 60\% mahasiswa belum memahami konsep logika matematika dengan baik dan benar. Pada konsep logika matematika, miskonsepsi hanya terjadi pada mahasiswa yang berlatar belakang pendidikan MA dan SMA. Mahasiswa yang berlatar belakang pendidikan SMK tidak mengalami miskonsepsi pada konsep logika matematika. Namun, mereka lebih cenderung mengalami ketidaktahuan konsep.

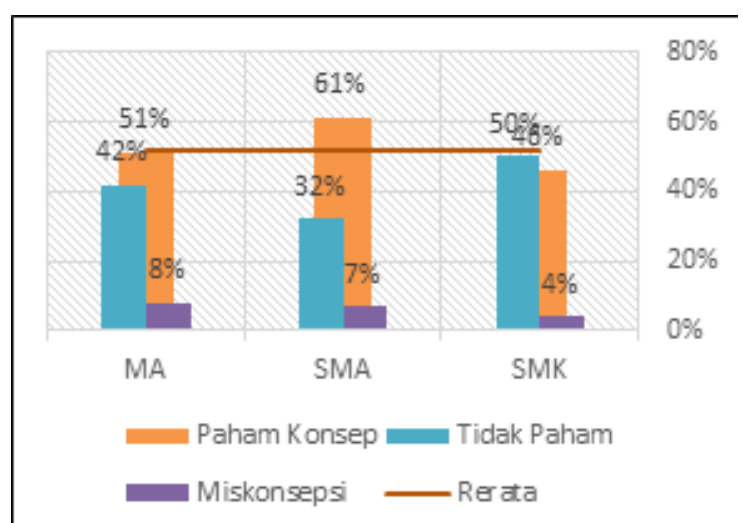

Gambar 9. Pemahaman Mahasiswa Terhadap Konsep Logika Matematika Menurut Latar Belakang Pendidikan Sebelumnya

Ketidakpahaman konsep terjadi secara merata pada materi pernyataan dan bukan pernyataan, modus ponens, modus tollens, silogisme, penarikan simpulan secara langsung, penarikan simpulan secara tidak langsung dengan kontradiksi, penarikan simpulan secara tidak langsung dengan kontraposisi, penarikan simpulan dengan induksi matematika. Sementara miskonsepsi terjadi pada materi penarikan simpulan secara tidak langsung dengan kontradiksi dan kontraposisi. Sebagian mahasiswa mengalami kekacauan pemahaman terhadap keduanya.

\section{PENUTUP}

\section{Simpulan}

Secara umum, terdapat dua problematika utama yang dihadapi mahasiswa calon guru sekolah dasar atau madrasah ibtidaiyah di IAIN Ponorogo. Pertama, masih rendahnya pemahaman terhadap konsep dasar matematika. Logika matematika merupakan materi dengan angka ketidakpahaman tertinggi dibandingkan materi lain. Ketidakpahaman konsep tersebut tersebar secara merata pada masing-masing kelompok mahasiswa, baik yang berasal dari MA, SMA, 
maupun SMK. Namun demikian, angka ketidakpahaman konsep pada mahasiswa yang berasal dari SMK cenderung lebih tinggi. Kedua, terjadinya miskonsepsi. Miskonsepsi terbanyak terjadi pada materi bilangan dan operasi aljabar. Namun demikian, meskipun dalam jumlah terbatas, ditemukan juga miskonsepsi pada konsep matematika dasar lainnya. Miskonsepsi cenderung terjadi pada mahasiswa yang berasal dari SMA dan MA.

\section{Saran}

Berpijak pada simpulan di atas, dapat diberikan beberapa rekomendasi sebagai berikut. Pertama, perlunya dilakukan pre test untuk memetakan kemampuan awal mahasiswa baru terhadap konsep matematika dasar. Kedua, perlunya kelas matrikulasi khusus mahasiswa yang tidak memahami konsep dan mengalami miskonsepsi pada konsep dasar matematika. Ketiga, mahasiswa yang merasa memiliki pemahaman yang rendah terhadap konsep dasar matematika, perlu melakukan akselerasi dalam belajar matematika.

\section{DAFTAR PUSTAKA}

Ainiyah, Lutfia Afifatul, and Sugiyono Sugiyono. "Identifikasi Miskonsepsi Siswa Dalam Materi Geometri Pada Pembelajaran Matematika Siswa Kelas VIII SMP Negeri 1 Punggelan." Jurnal Pendidikan Matematika-S1 5, no. 1 (2016).

Herutomo, Rezky Agung, and Tri Edi Mulyono Saputro. "Analisis Kesalahan Dan Miskonsepsi Siswa Kelas VIII Pada Materi Aljabar." Edusentris 1, no. 2 (2014): 134-145.
Irawan, Edi. "Analisis Miskonsepsi Mahasiswa STKIP PGRI Pacitan Pada Mata Kuliah Matematika Dasar Pokok Bahasan Logika Ditinjau Dari Gaya Kognitif Mahasiswa." PhD Thesis, Thesis pada PPs-UNS: Tidak dipublikasikan, 2012.

Irawan, Edi, Riyadi Riyadi, and Triyanto Triyanto. "Analisis Miskonsepsi Mahasiswa STKIP PGRI Pacitan Pada Mata Kuliah Pengantar Dasar Matematika Pokok Bahasan Logika Ditinjau Dari Gaya Kognitif Mahasiswa," 2012.

Kemendikbud, Balitbang. "TIMSS Infographic," 2016.

Menteri Pendidikan dan Kebudayaan. "Permendikbud Nomor 21 Tahun 2016 Tentang Standar Isi Pendidikan Dasar Dan Menengah," 2016.

Miles, Matthew B., and A. Michael Huberman. Qualitative Data Analysis: An Expanded Sourcebook. London: Sage Publications, 1994.

Moleong, Lexy J. Metode Penelitian Kualitatif. Bandung: Remaja Rosdakarya, 2007.

Ramlah, Ramlah, Dani Firmansyah, and Hamzah Zubair. "Pengaruh Gaya Belajar Dan Keaktifan Siswa Terhadap Prestasi Belajar Matematika (Survey Pada SMP Negeri Di Kecamatan Klari Kabupaten Karawang)." Majalah Ilmiah SOLUSI 1, no. 03 (2015).

Soedjadi, Rachmadi. Kiat Pendidikan Matematika Di Indonesia: Konstatasi Keadaan Masa Kini Menuju Harapan Masa Depan. Direktorat Jenderal Pendidikan Tinggi, Departemen Pendidikan Nasional, 2000. 
$114 \mid$

Suherman, Erman. Strategi Pembelajaran Matematika Kontemporer. Bandung: UPI, 2003.

Sukmadinata, Nana Syaodih. Metode Penelitian Pendidikan. Bandung: Remaja Rosdakarya, 2005.

Susanah. Strategi Pembelajaran

Matematika. Jakarta: Universitas Terbuka, 2008. 